\title{
Social protection for the poor in Latin America
}

\author{
Norman Hicks \\ nhicks@worldbank.org \\ Confronted with recurrent macroeconomic shocks, govern- \\ Quentin Wodon \\ ments in Latin America and the Caribbean have increasingly \\ qwodon@worldbank.org \\ been concerned about establishing or strengthening systems \\ World Bank \\ of social protection and safety net programmes. The goal of \\ these programmes is to help mitigate the impact of shocks \\ on the poor before they occur, and to help the poor cope \\ with the shocks once they have occurred. In this paper, we \\ focus on publicly funded or mandated safety nets function- \\ ing as risk-coping mechanisms. The paper reviews the char- \\ acteristics of a good safety net, in comparison with the main \\ types of safety nets currently in place, and finds in general \\ that no single programme meets all of the criteria in terms \\ of efficiency and effectiveness, although some are better than \\ others. Finally, what has been the actual record in terms of \\ protecting the poor through targeted public spending dur- \\ ing crises? The paper finds that because of fiscal constraints \\ during a crisis, social spending is often pro-cyclical when \\ ideally it should be counter-cyclical. Ironically enough, so- \\ cial protection spending itself does not appear to be pro- \\ tected.
}




\section{The context: persistent poverty and vulnerability to macroeconomic shocks}

The Latin American and Caribbean region has been plagued by macroeconomic shocks over the last twenty years, with serious consequences for the poor (see Glewwe and Hall, 1998; Lustig (ed.), 1995; Lustig, 1999; Ganuza, Taylor and Morley, 1998). Such shocks are so-called "covariant" shocks (Holzmann and Jorgensen, 1999) which affect the real incomes of a large share of the population, typically through a reduction in both real hourly wages (via inflation) and the number of hours worked (via unemployment or underemployment). Beyond these income effects, which may vanish once growth resumes, macroeconomic shocks may also have longer-term consequences. For example, the reduction in the quantity and quality of public health care due to budgetary cuts during a crisis may induce irreparable damage. Also, when coping with a crisis, parents may send their children to work in order to compensate for their own loss of income. If there is substitution between child labour and schooling, and if the children do not return to school at a later stage, they will incur longterm wage losses due to their lower endowment with human capital (Wodon and Siaens, 2000). All this may help explain why De Janvry and Sadoulet (1999) find evidence that the increase in poverty that follows a macroeconomic shock may be larger than the subsequent reduction in poverty with growth.

There are signs that the reforms enacted in many countries of the region in the 1990s have been bearing at least some fruits. Wodon (2000a) estimates that in 1996, slightly more than one-third of the population of the region $(36.7 \%)$ was poor (i.e., not able to cover

$\square$ This paper was prepared for the XII Seminario Regional de Política Fiscal held in Chile in January 2000. It is based in part on the last chapter of a regional study on poverty and policy (Wodon, 2000a) completed with funding from the Regional Office for Latin America and the Caribbean of the World Bank (Chief Economist, Guillermo Perry). The authors are grateful to Ana-María Arriagada, Judy Baker, Charles Griffin, Margaret Grosh, Kathy Lindert and William Maloney for the valuable discussions held with them. The views expressed in this paper are those of the authors, and do not necessarily represent those of the World Bank, its Executive Directors, or the countries they represent. their basic food and non-food needs), and one out of every six persons $(16.1 \%$ ) was extremely poor (i.e., not able to cover even their basic food needs). This represents some progress compared with 1992, when the incidences of poverty and extreme poverty were both higher. However, the absolute number of the poor has not been reduced to the same extent, due to population growth. Moreover, if the comparison is made with 1986 instead of 1992, the numbers of the poor and extreme poor in 1996 have risen considerably (see Lustig and Arias (forthcoming) for a survey of poverty estimates). Projections of further poverty reduction between 1996 and 1998 using elasticities of poverty reduction to growth and actual levels of growth observed in the region suggest only limited gains in percentage terms, with the numbers of the poor and extremely poor remaining constant. ${ }^{1}$

In addition to high levels of poverty, Latin American households are affected by instability of income and employment. While the level of instability is often thought to be linked with the current trends towards globalization, De Ferranti, Perry and others (2000) show that instability has not grown over time, and it is no worse in Latin America than in other developing regions. Still, there is much more instability in Latin America than in the OECD countries, and openness may have resulted in a widening of wage differentials between more and less skilled workers. ${ }^{2}$ Moreover, while the current changes in labour markets should ultimately bring net positive aggregate gains, they may induce idiosyncratic (i.e., household-specific) shocks for individuals who lose their jobs at a time when the region has not yet fully developed systems of social protection.

\footnotetext{
${ }^{1}$ The region has performed better in terms of non-monetary indicators of well-being, with improvements for adult illiteracy, infant mortality, life expectancy, gross secondary school enrollment, and access to safe water.

2 There is no convincing body of empirical evidence on many of these issues. Lustig and Arias (forthcoming) argue for example that there have been widening returns to skills, but Gill (1999) suggests that the empirical evidence is still very much mixed. See for example Fajnzylber and Maloney (1999).
} 
TABLE 1

Latin America and the Caribbean: Number of poor

and extremely poor, 1986-1998

\begin{tabular}{cccccc}
\hline Year & $\begin{array}{c}\text { Population } \\
\text { (millions) }\end{array}$ & $\begin{array}{c}\text { Percentage of population } \\
\text { in a state of poverty }\end{array}$ & $\begin{array}{c}\text { Number of poor } \\
\text { (millions) }\end{array}$ & $\begin{array}{c}\text { Percentage of population } \\
\text { in a state of extreme poverty }\end{array}$ & $\begin{array}{c}\text { Number of extremely poor } \\
\text { (millions) }\end{array}$ \\
\hline 1986 & 407.38 & 33.75 & 137.49 & 13.32 & 54.26 \\
1989 & 430.98 & 38.26 & 164.89 & 17.59 & 75.81 \\
1992 & 454.65 & 39.65 & 180.27 & 18.65 & 84.79 \\
1995 & 478.21 & 36.92 & 176.56 & 15.94 & 76.23 \\
1996 & 486.06 & 36.74 & 178.58 & 16.10 & 78.26 \\
1998 & 501.87 & 35.83 & 179.84 & 15.55 & 78.05 \\
\hline
\end{tabular}

Source: Wodon (2000a). Poverty numbers for 1998 are based on projections, not surveys.

TABLE 2

Latin America and the Caribbean: Subjective perceptions

of changes in living standards

(Percentages)

\begin{tabular}{lrrrr}
\hline & Better & Same & Worse & No reply \\
\hline $\begin{array}{l}\text { Taking everything into consideration, would you say that your parents lived better, } \\
\text { the same, or worse than how you live today? }\end{array}$ & 61.2 & 22.0 & 14.4 \\
$\begin{array}{l}\text { And regarding your children, do you believe that they will live better, the same, } \\
\text { or worse than how you live today? }\end{array}$ & 46.1 & 20.7 & 22.0 & 11.2 \\
\hline
\end{tabular}

Source: 1999 poll by the Wall Street Journal, quoted by Rodrick (1999).

In these circumstances, it should not be surprising that there is some degree of malaise in the region. While average levels of real per capita income have risen in the majority of Latin American and Caribbean countries in the 1990s, this may not yet have been translated into improvements in subjective perceptions of welfare. Table 2 presents the results of a 1999 opinion survey conducted by the Wall Street Journal in fourteen Latin American and Caribbean countries. Almost two-thirds of the respondents believe that their parents had a better life than they do, and less than half believe that their children will have a better life than themselves. This pessimism probably reflects both a feeling of economic insecurity and the relative Latin American and Caribbean lack of progress in reducing poverty observed over the last two decades and documented above.

There are no easy answers to the difficulties and uncertainties faced by poor households in Latin America and the Caribbean. Macroeconomic policies promoting stable and broad-based economic growth certainly help in reducing poverty, but they are not enough. Governments in the region have increasingly been concerned about establishing or strengthening systems of social protection and safety net programmes that help mitigate the potential impact of economic shocks before they occur and help the poor to cope with these shocks after they have occurred. In this paper, we focus on publicly funded or mandated safety nets functioning as risk-coping mechanisms. What are the characteristics of good public safety nets? What are the main types of safety nets currently in place in the countries of the region? Which programmes should be protected or expanded during economic crises? Finally, what has been the actual record in terms of protecting the poor through targeted public spending during crises? This paper provides tentative answers to these questions. Section II below introduces the reader to the main concepts used in the literature on social protection and safety nets within the context of the various ways in which households are affected by, and respond to shocks. Section III presents the main types of programmes currently in place, with their respective strengths and limitations. Section IV uses data on seven Latin American countries to assess the actual record in protecting the poor through safety nets during crises. Finally, section V contains a brief conclusion. ${ }^{3}$

\footnotetext{
${ }^{3}$ Several authors have recently reviewed the literature on social protection, safety nets, and crises. They include Klugman (1999) for safety nets, Dar and Tzannatos (1999) on active labour market programmes, Karni (1999) on unemployment insurance, and Ezemenari and Subbarao (1999) on social assistance. The InterAmerican Development Bank (in February 1999) and the World Bank (in June 1999) have held conferences on these topics. For a discussion of social protection within the context of globalization, see also De Ferranti, Perry and others (2000).
} 
II

\section{The goal: designing good safety nets and social protection systems}

A recent World Bank paper on social protection strategy (World Bank, 1999; see also Holzmann and Jorgensen, 1999) places social protection in the context of social risk management. It divides social risk management strategies into three types: risk reduction, risk mitigation and risk coping. Risk reduction covers macroeconomic management, regulations, and institutional development policies that help prevent crises from occurring. While these prevention policies are important, they are too general to be part of the social protection system, which consists mainly of mitigation and coping strategies. Risk mitigation strategies are put in place before a shock, to reduce its impact once it occurs. They include for example income diversification and insurance mechanisms, both formal and informal. Risk coping strategies, for their part, are implemented after a shock to deal with the impacts of the shock not covered by risk mitigation policies. Table 3, taken from Gill (1999), provides an overview of some of the main government and private sector policies.

In this paper, we focus on publicly provided or mandated instruments for assisting private individuals in coping with shocks (the bottom cell in the middle column of table 3). This does not mean that we do not take into account private coping strategies ${ }^{4}$. There are of course linkages between private and public coping strategies (see for example Ezemenari, 1997, for

\footnotetext{
${ }^{4}$ To cope with the income losses induced by shocks, the poor adopt a wide variety of strategies. These may include moving from formal to informal sector employment; working longer hours and/or working at a second job; promoting the labour force participation of additional family members such as spouses and children; selling (or consuming in the case of farmers) productive and other assets, including stocks; migrating temporarily or permanently in order to search for employment opportunities; reducing consumption patterns, including restricting the food intake of family members, taking children out of school to reduce education expenditures, or postponing health care expenditures; relocating and/or restructuring households, for example by having several families living under one roof; and drawing on outside help both in kind and in cash, including support from local communities, friends and relatives, and private institutions such as NGOs (this in turn highlights the role of social capital). An interesting paper about the gender dimension of these strategies is Cunningham (1998).
}

transfers). As mentioned in the introduction, some private short-term strategies may have permanent effects that make it difficult to reduce poverty in the longer term. This is the case when the nutrition of certain family members suffers. It is also the case if children are removed from school and are put to work ${ }^{5}$. In more general terms, publicly funded or mandated social protection programmes and safety nets represent an attempt to protect the poor against the risks that arise from shocks, whether the shocks are foreign or domestically induced, and whether they are covariant or idiosyncratic. As already mentioned, an economic crisis produces a covariant shock, whereby many people are affected at the same time. But even in normal times, households can be affected by idiosyncratic shocks such as death, illness or loss of employment. One should differentiate between the social safety nets which should be in place at all times to deal with idiosyncratic shocks, and the programmes which are specifically designed to help large numbers of poor people suffering from temporary adverse covariant shocks (World Bank, 1999).

There are usually more mechanisms available for coping with idiosyncratic than for covariant shocks, and the fiscal implications of the two types of shocks are clearly different. However, even among the programmes

\footnotetext{
5 Although the substitution effects between work and schooling are likely to be partial due to the possibility for the parents to reduce the time devoted by the children to leisure (Ravallion and Wodon, 2000a), it has been estimated that on average, for six Latin American countries, the reduction in the probability of going to school when a child is performing paid work varies from $21 \%$ to $67 \%$ depending on the sample (Wodon and Siaens, 2000; the estimates include controls for a wide range of other variables affecting the decision to go to school and/or to work, so that they are net marginal effects). This substitution between work and schooling reduces the human capital endowment of working children to the extent that working children may expect on average a loss of about $7 \%$ of their discounted lifetime earnings when they are put to work, even after taking into account their positive earnings when working as children and the higher level of experience accumulated because of work at an early age. Clearly, the magnitude of the long-term losses due to child labour calls for the design of programmes that help parents keep their children in school, especially during economic crises.
} 
TABLE 3

Latin America and the Caribbean: Classification of

government and private risk management measures

\begin{tabular}{|c|c|c|}
\hline Nature of measure & Government & Private sector \\
\hline $\begin{array}{l}\text { Mainly prevention } \\
\text { (risk-reducing) } \\
\text { Regulatory } \\
\text { Taxpayer-funded } \\
\text { Universal }\end{array}$ & $\begin{array}{l}\text { Macroeconomic policies } \\
\text { Financial regulations } \\
\text { Infrastructure investments } \\
\text { Labour-related regulations } \\
\text { Human capital investments }\end{array}$ & $\begin{array}{l}\text { Infrastructure investments } \\
\text { Human capital investments } \\
\text { Portfolio diversification }\end{array}$ \\
\hline $\begin{array}{l}\text { Mainly insurance } \\
\text { (risk-mitigating) } \\
\text { Inter-temporal transfers } \\
\text { Premium-funded } \\
\text { Non-poor and poor }\end{array}$ & $\begin{array}{l}\text { Unemployment insurance } \\
\text { Severance funds } \\
\text { Job protection statutes } \\
\text { Public works guarantees }\end{array}$ & $\begin{array}{l}\text { Individual savings } \\
\text { Sale of assets (e.g. land) } \\
\text { Labour force participation }\end{array}$ \\
\hline $\begin{array}{l}\text { Mainly assistance } \\
\text { (risk-coping) } \\
\text { Within-period transfers } \\
\text { Taxpayer-funded } \\
\text { Targeted: focus on poor }\end{array}$ & $\begin{array}{l}\text { Public works programmes } \\
\text { Means-tested cash transfers } \\
\text { Conditional cash transfers } \\
\text { Commodity transfers }\end{array}$ & $\begin{array}{l}\text { Inter-household transfers } \\
\text { Community solidarity } \\
\text { Support from NGOs } \\
\text { Public-private partnerships }\end{array}$ \\
\hline
\end{tabular}

Source: Gill (1999).

designed to deal with covariant shocks, one can identify a number of alternatives. These include:

- Emergency employment programmes involving public works, often using labour-intensive methods, commonly called "workfare";

- Social funds which establish special programmes, usually in rural areas, for financing small-scale public works identified by local community groups;

- Nutrition and food interventions, particularly those targeted at vulnerable groups such as children and pregnant women. These may take many forms, including food distribution, food stamps, and food served in schools or community kitchens;

- Systems of direct cash grants targeted at the poorest, which may be conditioned on favourable behaviour (such as school attendance and/or visits to health centres);

- Other instruments, such as pensions and unemployment insurance, including systems of mandatory severance payments upon termination.

Another way of organizing the discussion is to look at the programmes in terms of the age groups they serve, in view of the fact that the different age groups have different needs. ${ }^{6}$ People in the youngest age groups are generally at greater nutritional risk than other groups,

${ }^{6}$ This idea was suggested by Ana María Arriagada. See Appendix for details. while for adults, the principal problem may be one of employment. For the elderly, the critical problems are maintaining sufficient income to meet basic needs, and adequate health care access.

Within Latin America and the Caribbean, almost all the countries currently have some mix of the above programmes in varying degrees. However, very few if any of the programmes completely fulfill the criteria of an ideal safety net, which should have the following characteristics: ${ }^{7}$

- It should be based on a sound analysis of who is likely to be affected the most by crises, and what kinds of coping mechanisms are normally used by those affected;

- It should provide sufficient coverage of the population to be reached, particularly the most vulnerable and excluded groups;

- It should be well targeted on the poor, with clear eligibility and termination rules, so that access is simple and predictable;

- It should be supervised by well-functioning institutions already in place;

- It should be counter-cyclical (i.e., it should receive more funding when there is an economic crisis), and in some cases it should be implemented automatically according to pre-agreed triggers, such as a rise above a given level of unemployment or poverty;

${ }^{7}$ For a fuller discussion of the criteria see Grosh (1995). 
- It should be fiscally sustainable;

- It should be able to provide benefits quickly, with as large as possible a share of the costs being spent on net increases in incomes;
- It should complement, not substitute for, private safety net programmes and other social protection mechanisms;

- It should be scaled back when the crisis is over.

\section{III \\ The tools: types of safety nets and social protection programmes}

\section{1. "Workfare" programmes}

These programmes provide employment through specifically designed public works projects. The classic example is "Trabajar" in Argentina. In this programme, projects are identified by local governments, NGOs and community groups, and can provide employment for no more than 100 days per participant. Project proposals are reviewed by a regional committee, and projects with higher poverty and employment impacts are specially favoured ${ }^{8}$. Workers hired by the project are paid by the government, specifically the Ministry of Labour. The other costs are financed by local authorities. Examples of eligible projects include the construction or repair of schools, health facilities, basic sanitation facilities, small roads and bridges, community kitchens and centres, and small dams and canals ${ }^{9}$

\footnotetext{
${ }^{8}$ In a recent reform of the "Trabajar" programme, several steps were taken to improve its performance. The focus of the reform was placed on increasing community participation and funding in the choice of the projects to be financed. "Trabajar" now works in collaboration with local community groups, NGOs and municipalities which present projects for selection. Projects must first be approved for technical feasibility. Next, they are selected on a points basis. More points are awarded to projects which are located in poorer areas, yield larger public benefits, are sponsored by well-regarded community groups or NGOs, and reduce labour costs below the minimum wage. These new features have improved targeting both at the geographic and individual levels. The involvement of local groups has also improved the quality of monitoring and feedback for the projects.

${ }^{9}$ These activities are fairly similar to those financed by social funds (see below). One of the differences between a social fund project and a workfare project is that the workfare project is likely to be supervised by local authorities, rather than by independent agencies, and execution is typically not contracted to the private sector, but is carried out by the sponsoring agency, which can include local and provincial governments, private groups, and national
}

The projects financed by "Trabajar" are limited to poor areas as identified by a poverty map. Moreover, wages are set to be no higher than $90 \%$ of the prevailing market wage, so that the workers have an incentive to return to private sector jobs when these are available. Thus, the programme involves self-targeting as well as geographic targeting. Overall, targeting of the poor under "Trabajar II" (the second round of the project) has been reported to be quite good, with $75 \%$ of the funds reaching the bottom $20 \%$ of the income distribution, and $40 \%$ reaching the bottom $5 \%$. However, the supply of jobs in the programme depends on budgetary allocations as well as the ability of local communities to identify viable projects. As good as it is, "Trabajar" has provided employment to no more than $1 \%$ or $2 \%$ of the labour force, at a time when unemployment has ranged from $13 \%$ to $18 \%$ of that force.

Large "workfare" programmes were also implemented by the government of Chile during the period 1975-1988. The objective of these programmes was to absorb workers displaced from the public sector, and to reduce unemployment during the adjustment period. As in the case of "Trabajar", these programmes provided employment in emergency public works, including maintenance and repairs to roads and schools, construction of parks, forestry projects, etc. The programmes were administered by municipalities, and were gradually built up to a peak in 1983, when they employed about $13 \%$ of the total work force (over 500,000 workers), while the unemployment rate stood

organizations. Another difference is that workfare programmes have the generation of employment and income as their priority, while social funds focus more on the quality of the infrastructure produced. 
at $17 \%$. The programmes were gradually reduced as private sector employment increased, and finally phased out completely in 1988. The two largest programmes offered manual labour at very low wages, to ensure selftargeting. Most of the workers were unskilled, and they received one-fourth of the then current minimum wage (about one-half of the market wage). A quarter of the participants were women. However, while the programme was considered successful in terms of reducing poverty and the social impact of unemployment, the quality of the public works produced was notably low, particularly as the programme expanded in size. In addition, it is not clear that all the workers in the programme would have been unemployed without the programme. An evaluation found that $32 \%$ of the participants had no work experience prior to participating in the programme, and $46 \%$ had retired voluntarily before joining the programme. Many of those with no experience were women who went to work for the first time (University of Chile, 1992).

The advantages of workfare programmes include their ability to expand quickly during a crisis, once the basic mechanisms have been established, and to reach the poor through area targeting and, within poor areas, through self-targeting thanks to the low wages. But a problem with these programmes is that the cost of generating one dollar in additional income for the poor through public works is typically large, in the range of three dollars or more. To understand why, the measure of cost effectiveness and its decomposition proposed in Box 1 are useful.

The measure of cost effectiveness used is the share of total programme costs which reaches the poor through net increases in earnings. Modifying slightly the formula provided in Ravallion (1999), as indicated in Box 1, this share can be seen as a function of four key parameters: the proportionate wage gain, the targeting performance, the wage share, and the budget leverage. A reasonable value for the proportionate wage gain may be 0.5 , because workfare wages are low and the poor typically find some other way to generate resources, for example through part-time informal employment, when they do not have access to the programmes. Because of the self-selection involved and the priorities given to poor areas, targeting performance may be good, at about 0.8 . The wage share can often be obtained from administrative records by multiplying the number of work days created by the programme by the wage rate, and dividing this amount by the total cost of the programme. In many cases, the wage share will not exceed 0.7. Finally, when the programme is almost entirely financed by the central government (even though project selection may be done at the local level), the budget leverage is equal to one (in the case of "Trabajar" there is budget leverage, but while this saves money for the central government, it still has to be paid by local governments). The measure of cost effectiveness is obtained by multiplying the various parameters ${ }^{10}$. It thus typically costs three or more dollars to the national or federal government to transfer one dollar to the poor in additional wages.

The notion that it costs three or more dollars to transfer one dollar of income to the poor through workfare could be challenged, in that the benefits could be higher for two reasons ${ }^{11}$ :

First, the method presented in Box 1 does not take into account the benefits of the public works themselves, which can be substantial if the workers are put to good use. The problem, however, is that these benefits will be enjoyed during the whole life of the infrastructure built, while what the poor need in times of crisis is immediate income support. If the poor have high discount rates (which they do in general, but especially in times of crisis when their resources do not provide for basic subsistence), the discounted value of the benefits generated by the public works may be quite low. Moreover, since the emphasis is on job creation rather than investments, there may be a bias towards "make work" or prestige projects which may not be very valuable. This may be particularly true in a crisis, when a rapid expansion of the programme exhausts the backlog of viable projects.

Second, the method presented in Box 1 assumes that only the net proportionate wage gain must be taken into account for measuring the programme's impact. But in periods of high unemployment, it could be argued that at least part of the difference between the public works wage and what the programme participant would have earned by himself without the programme will be available as earnings for another worker who does not participate in the programme and who is also

\footnotetext{
${ }^{10}$ In our illustrative examples, this measure would be equal to $0.5 * 0.8 * 0.7=0.28$, in which case the total cost of generating one dollar in net additional wage earnings for programme participants is $1 / 0.28=3.6$ dollars. For an example of the econometric methods that can be used to measure with some precision the net wage benefit of workfare programmes using household surveys (i.e. the parameter NWB/W), see Jalan and Ravallion (1998).

${ }^{11}$ For a fuller discussion of these points, see Wodon (2000b) and Maloney (2000).
} 
Box 1

MEASURING THE COST-EFFECTIVENESS OF PUBLIC WORKS

In the spirit of Ravallion (1999), let us assume that without public works, an individual has a probability $\mathrm{F}^{*}$ of finding employment at market wage $\mathrm{W}^{*}$. Expected earnings are $\mathrm{F}^{*} \mathrm{~W}^{*}$. With public works, the individual earns the public works wage $\mathrm{W}$. If the individual can continue to search for private or self-employment while participating in public works, with probability $\mathrm{F}$ of finding such employment, the expected wage with public works is $\mathrm{FW}^{*}+(1-\mathrm{F}) \mathrm{W}$. The net wage benefit from the programme for the worker is NWB $=(1-\mathrm{F}) \mathrm{W}-\left(\mathrm{F}^{*}-\mathrm{F}\right) \mathrm{W}^{*}$. If the worker gets unemployment benefits or a subsistence allowance $S$, the wage benefit is reduced to NWB $=(1-F) W$ - $\left(\mathrm{F}^{*}-\mathrm{F}\right) \mathrm{W}^{*}$ - $\left(1-\mathrm{F}^{*}\right) \mathrm{S}$. If the programme costs $\mathrm{G}$ to the government per worker employed, a measure of costeffectiveness is the share of public expenditures transferred to workers as wage gain NWB/G. This measure can be decomposed as follows:

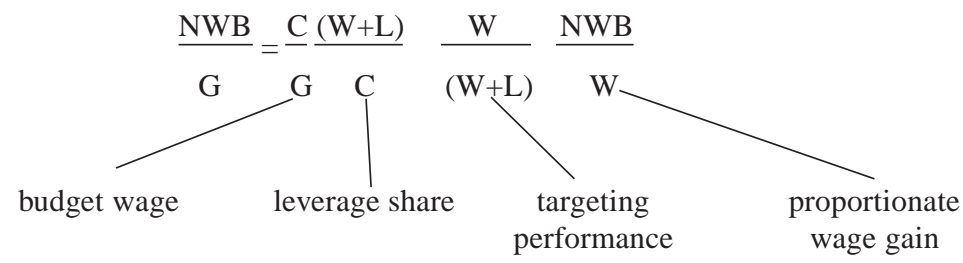

The determinants of cost-effectiveness are a) the leverage ratio $\mathrm{C} / \mathrm{G}$, where $\mathrm{C}$ is the total cost per worker including community funding; $b$ ) the wage share $(\mathrm{W}+\mathrm{L}) / \mathrm{C}$, where $\mathrm{W}$ stands for wages paid to the poor and $\mathrm{L}$ stands for leakage due to wages paid to the non-poor; c) the targeting performance $\mathrm{W} /(\mathrm{W}+\mathrm{L})$ which is the percentage of wages reaching the poor; and d) the proportionate wage gain NWB/W. This model can be extended to take into account the benefits of the infrastructure built by public works, but these benefits are not as immediate (see Wodon, 2000b, for a model and a discussion).

underemployed. At the extreme, the whole wage rate could be taken into account in the cost-benefit analysis, which would greatly enhance the cost-effectiveness of such programmes.

On the other hand, arguments could also be put forward to argue that the net transfers to the poor are lower than predicted by the decomposition in Box 1 . For example:

First, since workers are paid by local authorities, the opportunities for corruption and political bias are more pronounced. With "Trabajar", there remains some evidence of political influences in the choice of participants and gender discrimination (few women are selected in some areas).

Second, the poorest communities may not always be well positioned to submit proposals for projects and/ or to contribute to non-wage costs. In this case, the targeting performance of the programme may suffer, because the contribution of geographic targeting to overall targeting performance will be reduced.

Apart from Argentina and Chile, the experience of Mexico is also valuable for the assessment of the strengths and limitations of workfare programmes. In
Mexico's rural areas the Programa de Empleo Temporal (РET) provides off-season temporary employment below the minimum wage through public works. Employment is for up to 88 working days at $90 \%$ of the minimum wage. In 1999, 93 million work days and one million jobs were to be created. PET is an example of a programme which functions in normal times rather than only during crises, although it is restricted to certain periods of the year only. As expected, the projects are labour-intensive. Examples include irrigating land, paving roads, clearing land, improving housing, and installing water and sewerage systems. The data suggest good targeting, with the participants being poor and needing the temporary jobs more than non-participants because they do not benefit from occupations that keep them employed all year long. Yet, the programme does not reach the smallest (and probably poorest) rural communities. On average, PET communities are almost twice as large as non-PET communities. PET communities have better access than non-PET communities to electricity $(74 \%$ versus $60 \%)$, public phones $(33 \%$ versus $19 \%$ ), pre-school education ( $81 \%$ versus $67 \%$ ), primary schools ( $89 \%$ versus $82 \%$ ), and tele-secondary 
schools (distance education) (22\% versus $11 \%$ ). Part of the problem may be due to the higher (e.g., administrative) cost of reaching very small rural communities.

One might also consider job training programmes as a safety net, particularly if they can be modified during times of crisis. In Mexico, the Probecat programme was implemented in 1986 as a response to the growth in unemployment that followed the 1982 debt crisis and the subsequent structural adjustment policies. Today, the programme provides training for close to 500,000 beneficiaries per year in urban areas. A new evaluation of the programme suggests, however, that it does not have a statistically significant impact on employment and wages (Wodon and Minowa, 1999; see Revenga, Riboud and Tan, 1994, and STPS, 1998, for previous evaluations). These disappointing results are not very surprising, because most retraining programmes in OECD countries have been found to have limited impacts. One reason for this may be that the training is provided for too short a period of time (a few months) to provide skills valuable in the long run. Some job training programmes may in fact function as safety nets by providing temporary relief for the unemployed with a self-targeting mechanism not unlike that of public works programmes, since participants typically receive only the minimum wage. It is probably better to choose one goal or the other (training versus social protection), rather than trying to meet both goals with a single programme.

\section{Social investment funds}

Social investment funds (SIFs) were the original World Bank response to the social aspects of adjustment programmes, and some of the earliest funds (e.g., Bolivia's Emergency Social Fund created in 1991) were designed primarily to provide employment (Jorgensen, Grosh and Schacter, 1992). In fact, SIFs were started in part to avoid the problems associated with emergency public works (workfare) programmes. Yet almost all SIFs now have evolved into programmes designed to provide small-scale social infrastructure, particularly in rural and poor areas, using projects generated and executed at the local level. Therefore, social funds are not safety nets per se. Note that unlike workfare programmes, some social funds also finance programmes that do not involve construction or maintenance, such as nutrition programmes, technical assistance and micro-credit. When construction work is involved, it is not rare to see social funds using skilled manpower paid at market wages. This is because the quality of the infrastructure built is considered to be more important than the provision of employment for the poor. This is the case with the Honduras social fund, which originated from the transformation of an employment generation programme in the early 1990s but does not consider the objective of employment creation as its main priority nowadays. On the other hand, most social funds are usually targeted to poor areas through the use of a poverty map (or, in some cases, through the use of a map of unmet basic needs).

While both workfare and social fund programmes build projects in the public sector, there are important differences. The social fund finances the material and labour costs of a project, although some local labour may be donated as a community contribution. This varies across SIFs and countries. A workfare programme generally finances the labour cost of a project at the national or federal level, and asks that local governments or agencies provide for the material costs. Thus, there is a clear incentive in workfare programmes for the local agency to find labour-intensive methods of construction and choose labour-intensive projects. Since SIF projects are bid out to the private sector, often the most modern and capital-intensive construction methods are used, although in some cases social funds specify minimum employment levels to be attained in their operations.

Most social funds are agencies which are independent of the ministries -often attached to the Office of the country's President- which review and fund projects submitted by NGOs, local governments and other sponsoring agents. Their strong points include local community involvement and the ability to respond to local perceptions of needs, especially in rural areas where normal government expenditures often do not reach the poor. Social funds also have a better ability to avoid corruption and "make-work" projects. But they are not very good at providing safety nets, and they do not normally expand during a crisis to provide more employment. In fact, the amount of employment and income generation provided by social funds has historically been low. For instance, a review of social funds found that 10 major social funds provided employment on average equal to only $4 \%$ of the labour force (Goodman, Morley and others, 1997). Likewise, the monetary contribution in terms of wages was judged to be small, as well as the poverty reduction impact coming from the projects themselves. Social funds are better at improving the supply of health, education, and basic infrastructure services, with in some cases impacts 
on outcomes such as school enrollment rates, age-forgrade, or the incidence of illnesses (recent evaluations using household-level data include Pradhan, Rawlings and Ridder, 1998, for Bolivia, and ESA Consultores, 1999, for Honduras).

Still, one of the clear advantages of social funds is that they have strong organizations with relatively good systems for project management and monitoring. These organizations can be used in times of crisis for the delivery of social safety nets. The existing social fund in Honduras, for instance, has proven highly valuable in directing emergency assistance to local villages after Hurricane Mitch. One possibility therefore is to work with social investment funds to modify their operations during a crisis, as for example by putting more emphasis on labour- intensive projects and by having the fund involved in new, hard-hit areas. It is thus a good idea to identify labour- intensive projects in advance of a potential crisis, so that they will be ready for funding should a crisis come about.

\section{Nutrition and food programmes}

Nutrition and food programmes take a variety of forms. Subbarao, Bonnerjee and others (1997) have identified about thirty countries using food policies with redistributive aims. In these countries, price subsidies are used as often as feeding programmes and "food-forwork" requirements, and much more often than food quantity rationing and food stamps. In fact, many workfare programmes now providing wages in cash initially started as food-for-work programmes. As for direct feeding programmes, these provide food to needy recipients, through direct delivery of unprepared foods from a programme warehouse, delivery of prepared food from a community kitchen, or the provision of a lunch or breakfast for children in school ${ }^{12}$. Evaluations of nutrition programmes generally indicate that there is only a small, marginal improvement in nutrition compared to the case where the family receives an equivalent cash grant. This is because families may substitute free food for their own purchases, and largely use the savings for other purposes. However, even if a food programme is roughly equivalent in effect to a cash grant, there are fewer possibilities of diversion of funds, since food is less likely to be misappropriated than cash.

12 School feeding programmes are especially popular in Latin America. See for example Phillips, Sáenz and others (1995) on Honduras, Dall'Acqua (1991) on Brazil, and Jacoby, Cueto and Politt (1996) on Peru.
In addition, food is more likely to go to women, and be used to improve the welfare of the family, while cash is more likely to be used by men for lower-priority activities. An intermediate alternative between cash and food is the issue of food stamps. Food stamps have the added benefit of not requiring a complicated system of storage and transport of food, while making use of the already existing private food distribution network. In Honduras, the food stamp programme used to also cover medicines and school books. In Jamaica, the food stamp programme was introduced in place of general food subsidies, and has proven effective in raising the incomes of the poor (Grosh, 1992).

A common way of targeting food programmes is by linking distribution to a health programme, particularly maternal and child health care. In this way, the food serves as an incentive to attend the programme, and nutrition education can help improve the use of the food given out. As already mentioned, giving food to women also lessens the possibilities of it being diverted for sale in the market. Food programmes can also be designed to be self- targeted, if the food products given out are those consumed by the poor and not by the middle class. Alternatively, food distribution can take place at centres located in poor neighbourhoods. Such approaches can reduce the administrative burden of targeting programmes, but they increase the possibility of leakage to the non-poor. School lunch and breakfast programmes are also difficult to target at the individual level if it is desired to avoid stigmatizing some students within the school as being "poor." In many countries, schools from poor areas are targeted, but completely untargeted national programmes are also common. One benefit of these programmes is the incentive given to keep the children in school in order to have them fed, and the fact that they improve their learning abilities while in school (see Wodon and Siaens, 1999a, for an evaluation of the Mexican school breakfast programme). From a nutritional point of view, however, the prime beneficiaries of the programmes may be other members of the family, if the children are not fed at home because the parents know that they will receive a school lunch.

Food subsidies are another way to help the poor by reducing the cost of their consumption bundle (Besley and Kanbur, 1988). Means-tested food subsidies tend to be more effective than other subsidies in reducing inequality and improving welfare. For Mexico, for example, Wodon and Siaens (1999b) suggest that universal subsidies do not perform well for the reduction of inequality and the improvement of 
welfare. They compare three programmes: the now defunct universal subsidy for tortillas, a programme providing one kilogramme of free tortillas for households with income below two minimum wages, and a subsidized milk programme, also means-tested. Their main findings were as follows:

- Food subsidies are better than non-food subsidies. Subsidies for basic consumption goods such as tortillas reduced inequality, especially in urban areas, and more so than subsidies for utilities such as water and electricity. However, food subsidies generate price distortions and they are costly. Furthermore, a universal subsidy for tortillas is less effective than would be a similar generalized subsidy for the ingredients needed for making tortillas, such as corn flour.

- Within food subsidies, means-tested subsidies are better than universal subsidies. The marginal impact on inequality and welfare achieved with the universal tortilla subsidies does not come close to the welfare gains achieved with the means-tested subsidies.

Still, food subsidies may not represent a sound and costeffective investment for poverty reduction. Food subsidies and distribution systems can have negative incentive effects on the supply of labour (Sahn and Alderman, 1995). They can be badly targeted, with high leakage to the non-poor (Grosh, 1994; Cornia and Stewart, 1995). And, while self-targeting can be achieved to some extent by subsidizing goods consumed in larger quantities by the poor than by the nonpoor, this is no panacea (Tuck and Lindert, 1996). There has therefore been a tendency to reduce funding for food subsidies in favour of other programmes, for example in Mexico (Levy and Dávila, 1998).

\section{Conditional cash transfers}

Since food is fungible with money, one could argue that cash grants are the simplest and most direct way of providing safety net assistance. The use of cash grants also avoids the utility losses associated with in-kind support. In developed countries, and some advanced Latin American countries, cash payments to selected households are slowly becoming more common. Unconditional cash payments and similar forms of social assistance are usually targeted to women with dependent children, the disabled, the aged, and those unable to work. However, the problems of targeting and controlling cash payments make this approach difficult in poorer countries that lack good administrative arrangements. For instance, in Bolivia the Bonosol programme gave adult citizens an annual cash grant equal to four weeks' pay at the minimum wage. The attractiveness of the grant and the lack of screening or identification mechanisms resulted in widespread abuses, however, including double payments and payments to non-Bolivians.

An attractive alternative is to link cash grants to school attendance or other desirable behaviour. This system has been introduced in various degrees in such countries as Brazil (Bolsa Escola), Argentina (Beca Secundaria), Mexico (Progresa), and Honduras (PRAF), among others ${ }^{13}$. These programmes are not safety nets properly speaking, or at least they were not originally designed to function as compensatory safety nets during crises. Yet the programmes do provide valuable benefits which households can rely upon during crises, and these benefits can be increased during a recession if need be. In other words, as was the case with job training programmes and social investment funds, existing programmes providing conditional cash transfers can be expanded and modified to serve as safety nets during a crisis. In general, however, school-related grants will offer only a partial response to crisis situations, if only because the programmes are targeted at families with children already in school, so that some of the poorest who cannot afford to send their children to school are excluded from the programmes' coverage.

School-based conditional cash transfer programmes reduce the opportunity cost for poor parents of keeping their children in school. This opportunity cost is essentially the loss of child wages or of the value for the parents of the domestic work done by the children, which cannot be enjoyed when the children go to school. In many cases, this opportunity cost of schooling is difficult to estimate, and it is by no means obvious that the grants must necessarily be equal to the opportunity cost in order to persuade parents to send their children to school (Ravallion and Wodon, 2000a). Indeed, it is reasonable to think that the parents have an intrinsic interest in having their children go to school, either for altruistic

\footnotetext{
13 A rigorous evaluation of Mexico's Progresa scheme is being prepared by the Progresa staff with support from the International Food Policy Research Institute. Preliminary results are available in Progresa (1999). The International Food Policy Research Institute is also going to help in the evaluation of Honduras's Family Allowance Programme (PRAF), with a design combining demandand supply-side interventions.
} 
motives, or for the future benefits that intergenerational transfers provide once the children reach adulthood. In some countries, however, the level of conditional grants appears to be high. In the case of Progresa in Mexico, for example, in order to justify the relatively high level of the Progresa grants it has been argued that apart from providing incentives to accumulate human capital, they also improve the families' overall quality of life. Yet there may be more cost-effective ways of improving the quality of life of the programme's beneficiaries. On the other hand, as shown by Wodon, González, and Siaens (2000), when the value of the grants is low, demand-side schooling interventions may exclude the poorest. More work is needed to measure the many trade-offs involved.

At what level of schooling should the grants be provided? This will depend on the characteristics of the country. In Brazil and Argentina, the programmes focus on secondary school students, since these are the children who are more likely to be pulled out of school during a crisis. In Honduras, the programme focuses on the first four years of primary school. In Mexico, the programme covers the end of primary schooling and the lower secondary school cycle. In Venezuela, the programme covers primary school children. In some cases, these programmes are tied not only to attendance but also to school performance, including passing on to the next grade. While this may provide valuable incentives, one has to make sure that such conditions do not exclude the poorest children, who may have more difficulties in succeeding at school.

How should the grants be targeted? The experience of Progresa is interesting (Skoufias, Davis and Behrman, 2000). The programme uses a three-stage targeting mechanism. First, poor rural localities are selected for participation. Next, poor families are selected within participating communities, using a multivariate discriminant analysis. Third, local communities may review Progresa's selection and reclassify poor families as non-poor and vice versa. This targeting mechanism is basically sound, and the results appear to be good. One concern is that the level of community involvement remains marginal. The targeting process is centralized in part due to the desire to avoid political interference in the choice of beneficiaries. Nevertheless, more efforts could be made to promote the role of communities in targeting. Another related question relates to the need for targeting within poor communities. The higher the proportion of the poor in a community, the less the need to target within that community, especially if targeting is costly not so much administratively but rather in terms of social cohesion (those who do not get into the programme may envy those who benefit from it). In Honduras, where the PRAF programme is being modified in part on the basis of Progresa's experience, it has been decided to provide support to all the families residing in the poor communities that participate ${ }^{14}$.

Conditional cash transfer programmes can also be used to promote good health practices, including the consultation of local health providers. This is again the case with Mexico's Progresa scheme, where eligible families receive a transfer (both in cash and in kind through a nutritional supplement) for health purposes apart from the transfers related to schooling. In other words, Progresa aims at providing coordinated intervention for education, health and nutrition, in the hope that the impact of the whole programme will be larger than that of its individual parts. Of course, with Progresa as with the other programmes, in maximizing the impact of the school- and/or health-based interventions it is important to take care of supply-side issues. For example, Progresa has been successful in raising school enrollment and attendance at health care centres, but this has led to tensions on the supply side. Steps have been taken to coordinate Progresa's action with that of other ministries, such as those of education and health, but more may be needed to optimize demand- and supply-side interventions.

\section{Unemployment insurance and other programmes}

Unemployment insurance is common in Europe and North America, but relatively rare in Latin America, partly because of its high cost. On the other hand, the current labour legislation in many Latin American and Caribbean countries mandates a severance payment on termination which is a function of the number of years worked. Normally, this is about one month's salary for every year of service, up to some maximum. This may be supplemented by an unemployment insurance scheme (as in Argentina and Brazil for formal-sector workers) in which monthly contributions from payrolls and/or the employer entitle workers to a monthly payment over a limited time horizon, with the payment set low enough to reduce disincentive effects. But since the formal sector in many countries is less than half of

\footnotetext{
${ }^{14}$ It is important, when feasible, to use distributional weights in the evaluation of the targeting of social programmes and other interventions. For such an analysis, see for example Ravallion and Wodon (2000b), and Wodon and Yitzhaki (2000).
} 
the total work force, the coverage of unemployment insurance/severance payments is far from complete, and the exclusion of the informal and rural sectors means that these mechanisms miss those areas which contain many of the poor. Moving from a severance pay system to an unemployment insurance system could be beneficial if it reduces labour costs. However, unemployment insurance can also create moral hazard problems by subsidizing unemployment (as compared to workfare programmes, which subsidize employment). One important element here is to ensure that unemployment benefits are not so generous as to discourage the search for work. For this, both the level of the payments and the length of time workers can receive benefits must be monitored (for a review of OECD experience with labour market rigidities and unemployment insurance, see Nickell, 1997).

An alternative frequently mentioned is a system of Unemployment Insurance Savings Accounts (UISAs), under which workers would receive no "reward" upon losing their jobs, and they would suffer no "penalty" for finding a new job quickly. Each employed worker would make a fixed mandatory minimum contribution to his/her UISA each month, and additional voluntary contributions above the mandatory minimum levels would be permitted. Upon becoming unemployed, an individual worker would be entitled to withdraw a fixed maximum amount per month from his or her UISA (smaller withdrawals would also be permitted). When the individual's UISA balance falls to zero, or is seriously depleted, he/she would be entitled to unemployment assistance. The unemployment assistance would be financed through a tax levied on all wage earners. When workers retire with a positive balance in their UISA, they would be able to use that balance to top-up their pensions. Overall, the workers themselves would play a much larger role in financing their own support during periods of unemployment. The main advantage of UISAS is that they tend to set the incentives right, without creating distortions in the behaviour of employers and firms, since the funds taken out by an unemployed individual from his/her UISA directly reduce the individual's personal wealth by an equal amount, so that individuals fully internalize the cost of unemployment compensation. UISA systems are not without risks, and special interventions are likely to be needed to protect those workers who are younger, poorer and less well educated. For Chile, CastroFernández and Wodon (2000) suggest that although the redistributive impact per dollar spent on unemployment benefits of a UISA-based system would probably be smaller than the redistributive impact of Chile's current unemployment assistance system, the complementary unemployment assistance component of the system would still be highly redistributive, and it would probably have a much better coverage because the value of the benefits would be higher.

Finally, it is worth mentioning that there are several other types of social protection programmes that exist, including pensions for the elderly. Because many of the poor belong to the informal sector, they do not have access to the pensions provided by social security systems (likewise, those in the informal sector often lack access to other State-organized benefits such as low-income housing). For a discussion of pension issues for the poor, see Holzmann and Packard (1999). 


\section{IV}

\section{The constraints: fiscal space and administrative capacity}

\section{Are social protection programmes counter-cyclical?}

Good social protection programmes should expand during an economic crisis as unemployment grows and income levels decline. In other words, the programmes should be counter-cyclical: i.e., rising when the economy falls. In some countries, the system of safety nets is supported by automatic entitlements that force the public sector to spend more on those who need it. For instance, unemployment causes an increase in the numbers eligible for unemployment benefits, and declining incomes can increase the number of households eligible to receive cash or food assistance. But in most Latin American countries, there are no such automatic triggers. This is partly because the need to have counter-cyclical social protection programmes can conflict with the need to impose fiscal austerity during a recession. An economic crisis, whether domestically or externally induced, leads to a drop in output and consequently a fall in government revenues. But during a crisis, governments are reluctant to raise taxes, so maintaining high expenditure levels can lead to large budget deficits.
Let us consider the data presented in table 4. Both Argentina and Mexico suffered adverse shocks in 1995 (Mexico was first, Argentina followed). Per capita GDP in Argentina decreased by $5.32 \%$ between 1994 and 1995, while it went down by $4.93 \%$ in Mexico between 1994 and 1996. The share of GDP devoted to targeted social spending decreased a little in both countries, while the poverty rate increased, leading to an increase in the total number of poor people. The targeted spending per poor person decreased much more than per capita GDP, yielding an elasticity to growth (in this case to a recession) of targeted spending per poor person of about five in the two countries. During this recession, spending for the poor was thus highly pro-cyclical, whereas ideally it should have been counter-cyclical in order to protect the poor from the adverse macroeconomic shock.

The data in table 4 are based on one period in two countries only and on a number of assumptions for both the estimation of poverty and the categorization of social spending. It may be misleading to conclude that social protection declines in all countries during a crisis. Unfortunately, beyond point estimates of the elasticities of targeted spending to growth such as those presented

\begin{tabular}{|c|c|c|c|c|c|}
\hline & \multicolumn{4}{|c|}{$\begin{array}{l}\text { Argentina and Mexico: Targeted public spending } \\
\text { per poor person, 1994-1996 }\end{array}$} & \multirow[b]{2}{*}{$\begin{array}{l}\text { Targeted spending } \\
\text { per poor person } \\
\quad(1994=100)\end{array}$} \\
\hline & $\begin{array}{l}\text { Real per capita GDP } \\
\quad(1994=100)\end{array}$ & $\begin{array}{l}\text { Share of targeted social } \\
\text { spending in GDP }(\%)\end{array}$ & $\begin{array}{l}\text { Poverty rate } \\
\quad(\%)\end{array}$ & $\begin{array}{l}\text { Number of poor } \\
\text { people (million) }\end{array}$ & \\
\hline \multicolumn{6}{|l|}{ Argentina } \\
\hline 1994 & 100 & 1.24 & 21.6 & 7.5 & 100 \\
\hline 1995 & 94.68 & 1.21 & 27.2 & 9.6 & 63.12 \\
\hline$\%$ change & $-5.32 \%$ & & & & $-27.88 \%$ \\
\hline \multicolumn{6}{|l|}{ Mexico } \\
\hline 1994 & 100 & 1.36 & 46.95 & 42.04 & 100 \\
\hline 1996 & 95.07 & 1.23 & 60.93 & 56.51 & 67.30 \\
\hline$\%$ change & $-4.93 \%$ & & & & $-23.70 \%$ \\
\hline
\end{tabular}

Source: Wodon, Hicks and others (1999). The data for the two countries are not strictly comparable. Hence it should not be inferred that social protection spending is more pro-cyclical in one country than in the other. Note also that the Government of Mexico has made a substantial effort to increase targeted funding for the poor in recent years, for example by providing funding for Progresa. This is not reflected in the table. 
in table 4, the extent to which Latin American and Caribbean countries have provided counter-cyclical social protection is a question which has received surprisingly little attention. One problem is that the data on budget expenditures do not typically identify social protection or safety nets as a separate activity. Social protection programmes are scattered over various sectors such as health, education, social security, and welfare. However, data are available in some countries.

Wodon, Hicks and others (1999) use data for seven countries (Argentina, Bolivia, Chile, Costa Rica, Dominican Republic, Mexico and Panama) to test for the business cycle properties of targeted and social spending in Latin America. They first propose a theoretical model to analyse how targeted public spending for the poor may be affected by booms and busts. A government is said to be "pro-poor" if it gives reasonable weight to the poor in its social welfare function, if it considers a minimum level of basic needs that must be satisfied for the poor, if over time it raises this level of basic needs faster than GDP during a period of growth, and if it does not reduce the level of minimum basic needs during a temporary recession. If a government is pro-poor according to the above definition, the elasticity of targeted public spending to growth will be positive and larger than one during booms, and smaller than one during recessions. If the government is not pro-poor, the model predicts that the elasticity of targeted spending will always be smaller than or equal to one. The existence of an asymmetry between booms and busts in the elasticity to growth of targeted public spending for the poor when the government is pro-poor is then tested with the panel data on public expenditures. The results in table 5 suggest that governments are to some extent pro-poor and pro-social, because targeted and social expenditures are rising faster than GDP and total government spending during booms. While this is encouraging, the fact remains that during recessions, targeted spending is not protected. It decreases slightly faster than GDP (although the elasticities are not statistically different from one in table 5 in the case of a recession). Thus, even though governments can be considered as being pro-poor, targeted and social spending remain highly pro-cyclical. The evidence suggests that social protection programmes, instead of expanding quickly during a crisis, are actually contracting, in many cases as rapidly as other types of public spending ${ }^{15}$.

${ }^{15}$ Ravallion (2000) finds somewhat similar evidence with data for Argentina.
TABLE 5

Latin America (seven countries): Estimated elasticities of expenditures with respect to changes in GDP

\begin{tabular}{llc}
\hline & Growth $^{\mathrm{a}}$ & Recession \\
\hline Total government spending & 0.971 & 1.003 \\
Social sectors spending & $1.475^{*}$ & 1.128 \\
Social protection spending & $1.999^{*}$ & 1.391 \\
\hline
\end{tabular}

Source: Adapted from Wodon, Hicks and others (1999). Sample of 7 countries, with 97 observations.

a * denotes an elasticity statistically different from one at the $5 \%$ level.

The impact of a recession on targeted spending on the poor is even more negative than table 5 suggests. It can be shown that in Latin America, a one percentage point decrease in per capita GDP leads to at least a two percentage point decrease in targeted public spending per poor person. Half of this impact is due to the reduction in per capita GDP itself, which reduces spending even when the share of targeted spending with respect to GDP remains constant (the fact that the share remains constant is evidenced by the unit elasticity in table 5). The other half of the impact comes from the increase in poverty due to the crisis: i.e., the available targeted public spending must be shared among a larger number of poor people.

The fact that targeted programmes for the poor are not well protected may be surprising, given that these programmes represent only a small proportion of GDP (typically $2 \%$ or less) and a small proportion of total spending as well. One reason for the lack of protection for targeted spending may be related to the lack of bargaining power of the poor. Another reason why expenditure protection may be difficult during an economic and fiscal crisis is that the country must honour its debt service and a number of mandatory entitlement programmes, with consequently low levels of discretionary resources. In other words, if $30 \%$ of the budget is protected because of its safety net and poverty aspects, and $50 \%$ is for debt service and other programmes that cannot be cut, a $10 \%$ reduction in overall spending would produce a $50 \%$ cut in the remaining sectors. Given that the remaining sectors might include such sensitive areas as defence, justice and administration, this may not be a feasible solution, thereby forcing the government to abandon the idea of protecting funding for key social protection programmes. One message from this discussion is that prevention before a crisis is crucial, because during the crisis, it will always be difficult to protect the poor. 


\section{How can one select the programmes to be protected or expanded during a crisis?}

The objective during a crisis should be first to agree that key programmes that benefit the poor will not be cut back even though total government expenditures may be reduced. Next comes the difficult question of which specific programmes should be protected or even expanded. It is tempting to put on the list almost all programmes in basic health, education and nutrition. But not all programmes in the social sectors are equally effective in reducing poverty, and some programmes producing long-term benefits for the poor may be deferrable. In deciding which programmes to keep and expand during a crisis, an important criterion should be the cost-effectiveness of the programme in quickly channeling income or its equivalent in kind to the poor. As suggested in the case of workfare programmes, the cost-effectiveness of programmes depends on a number of parameters. Knowing these parameters beforehand helps in making a selection. Comparison of the costeffectiveness of alternative safety nets in smoothing consumption patterns for the poor via income generation, in-kind commodity distribution or commodity subsidies is one area where additional analytical work should clearly be done.

One element of a viable strategy -actually, one of the key parameters of the cost-effectiveness of safety nets- is the protection of programmes that have good targeting mechanisms for reaching the poor. Untargeted or universal welfare programmes are often fiscally impossible to sustain, particularly during a crisis. It is true that targeting beneficiaries by complicated means testing (i.e., intensive questioning over income and wealth) can be costly and not very reliable. This is why many World Bank-funded programmes have relied on geographic targeting, even though this can lead to substantial leakage. An alternative approach is the proxy means test, whereby likely recipients are interviewed and respond to questions concerning their living conditions, such as the type of housing in which they live, the availability of drinking water, the types of appliances possessed by the household, etc. Wodon (1997) has shown that these indicators are powerful means for avoiding the two types of errors that can be committed in targeting, namely identifying as poor a non-poor household, and as non-poor a poor household. For any given budget, good targeting also helps to improve coverage among the poor (i.e., what percentage of the poor actually receive programme benefits), which is an important advantage in Latin America, where coverage has often been low.
Variants of means-testing systems have been used, among others, for the CAS (Social Action Committee) cards in Chile, SISBEN (Beneficiary Identification System) in Colombia, SISFAM (Beneficiary Family Identification System) in Argentina, and Progresa in Mexico. In practice, people who apply for assistance are interviewed, and their score on the questionnaire determines their eligibility. The weights for the various indicators included in the questionnaire are based on estimated econometric relationships between the poverty status of a representative sample of households and their indicators. Grosh (1994) has estimated that the cost of targeting through proxy means testing or geographic targeting (definition of poor areas) need not be much higher than the cost of universal distribution (a reasonable mark-up would be $3 \%$ to $8 \%$ ), while producing substantial benefits. In a sample of untargeted programmes, only $33 \%$ of the benefits accrued to the lowest $40 \%$ of the population, whereas in targeted programmes $72 \%$ of their benefits reached that population.

Beyond the need to protect the consumption of the poor during a crisis, it is also clear that some existing health and education programmes not necessarily targeted to the poor should be preserved. It is possible that the demand for these programmes might go up if, for example, the losses in income due to unemployment or underemployment cause people to shift from private providers and private health insurance to public programmes. Likewise in the field of health, some programmes not targeted on the poor should be maintained because there are large externalities involved. This would be so, for example, in the cases of disease surveillance, immunization campaigns, malaria control, AIDS prevention, etc. Preserving access to basic (primary and lower secondary) education is not a shortterm safety net issue but, as discussed earlier, it does reduce the costs of a crisis over the longer term by avoiding cuts in education spending for the poor that eventually lead to a reduction in human capital, and thereby lead to lower productivity and income.

In order to be able to protect all the above programmes, it will be necessary to identify some programmes that can be reduced, put on hold, or eliminated. For example, some of the worse cases of misspent social spending in Latin America have been large subsidized housing programmes for the middle class, which are often mandated through earmarked taxes. While it may be impossible for a government to change these programmes quickly without major legislative or even constitutional authority, in some 
cases the need to reallocate spending due to an emergency or a crisis may facilitate fundamental changes. Other candidates for expenditure reduction may include subsidies, such as below-cost pricing for non-poor groups, for such services as electricity, water or urban transport. Better cost recovery for higher education (e.g., at the university level) and for some health care services may also help. Table 6 (the idea for which came from a discussion with $\mathrm{K}$. Lindert) gives a generic ranking based on common practice and observation, although the priorities may change depending on the country.

\section{Additional implementation issues}

There are several additional issues which must be considered when implementing safety nets. First, establishing new institutions that work effectively at the national level is difficult. Most social funds, for instance, take 2 to 3 years to get up and running at a level that reaches a substantial number of poor people. Under the pressure of time, it is much easier to work with existing institutions by providing them with support that enables them to expand their operations during a crisis. It is also often possible to expand safety net programmes that have already started on a pilot basis and that have been evaluated and proven effective. As a corollary, it might be useful to experiment with new programmes every now and then on a pilot basis, in order to evaluate their strengths and weaknesses and their ability to be expanded in case of need. Also, as indicated earlier, it may be possible to use existing in- stitutions running programmes for job training, social funds, or transfers for the distribution of emergency assistance when needed.

Second, not all governments possess the same capacity to administer programmes. In some countries, a simple programme that is not well targeted might be a better choice than a more complicated programme. Safety net programmes need to strike a balance between administrative capacity, fiscal sustainability, political acceptability, the scope of the intervention, and targeting efficiency. An additional problem is the relationship between the federal and provincial-level governments. The staff of multilateral development banks have traditionally established a dialogue with federal authorities, but a large part of social spending takes place at the provincial level. It may be necessary to agree to additional support from the federal budget for state, provincial or municipal budgets during a crisis if safety net programmes are operated locally. However, while decentralization has a number of advantages, it is not necessarily pro-poor, so that serious monitoring of sub-national authorities is needed.

Third, one problem encountered in many countries is the proliferation of small programmes throughout various parts of the government. Nutrition programmes, for instance, are found in the ministries of health, education, social development and agriculture, as well as in autonomous agencies belonging to the Office of the President. Training programmes are run by the ministries of education, labour and economic development. It is important to seek some sort of interministerial coordination in order to avoid overlaps and

\begin{tabular}{|c|c|c|c|}
\hline & \multicolumn{2}{|c|}{$\begin{array}{l}\text { Priorities in protecting programmes during } \\
\text { crises: a possible hierarchy }\end{array}$} & \multirow[b]{2}{*}{ Social protection/others } \\
\hline & Health & Education & \\
\hline High priority & $\begin{array}{l}\text { Immunizations } \\
\text { Disease control } \\
\text { AIDS prevention } \\
\text { Pregnancy care and } \\
\text { early child development }\end{array}$ & $\begin{array}{l}\text { Means-tested stipends } \\
\text { School breakfasts in poor areas } \\
\text { Special programmes for } \\
\text { indigenous populations }\end{array}$ & $\begin{array}{l}\text { Workfare programmes } \\
\text { Means-tested pensions for the elderly } \\
\text { Means-tested nutrition supplements }\end{array}$ \\
\hline Moderate priority & $\begin{array}{l}\text { Primary health care } \\
\text { posts and centres } \\
\text { Basic care in hospitals }\end{array}$ & $\begin{array}{l}\text { Basic education } \\
\text { (primary and lower secondary) } \\
\text { Scholarships for poor } \\
\text { students at universities }\end{array}$ & $\begin{array}{l}\text { Unemployment insurance } \\
\text { Social security } \\
\text { Social funds } \\
\text { Job training } \\
\text { Food subsidies }\end{array}$ \\
\hline Low priority & $\begin{array}{l}\text { Advanced curative care } \\
\text { in hospitals }\end{array}$ & $\begin{array}{l}\text { Free/low-cost university } \\
\text { education for non-poor } \\
\text { Research budgets }\end{array}$ & $\begin{array}{l}\text { Subsidized housing } \\
\text { Subsidies for } \\
\text { infrastructure services }\end{array}$ \\
\hline
\end{tabular}


duplication. In the longer term, it may be possible to combine or consolidate programmes, and to eliminate the programmes that are least effective. As mentioned earlier, a crisis can help in reorienting social budgets.

Fourth, in monitoring expenditure levels it is preferable in principle to use actual expenditures, rather than the amounts budgeted. However, actual expenditure levels are difficult to monitor in many countries because of the long lag involved in receiving

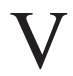

\section{Conclusions}

Economic shocks may lead to a decline in real income caused by loss of employment, a situation of underemployment, or a shift to less lucrative employment. Real wages may also be reduced by high levels of inflation. Changes in relative prices may have negative effects. The poor may also lose their access to essential public services for health, nutrition and education as a result of reduced government real spending. They may lose the value of their financial assets (however meagre) if these are not protected from bankruptcy by the financial system or by the public social security system. Or they may simply have to sell their assets. In all these potential effects and in many others, the poor are more vulnerable than the non-poor because their income may fall far more quickly below bare subsistence levels.

It is common practice to recommend that governments should protect key social protection programmes during a crisis and expand the social safety net. However, with fiscal resources shrinking at a time when the number of poor are increasing, it may be extremely difficult to do this. Still, one would hope at least that high-priority programmes will be less subject to cuts than other programmes. This is feasible because social safety nets represent only a small part of existing budgets. Yet this does not appear to be the case at present. Rather than being counter-cyclical, safety nets are as pro-cyclical as other types of public expenditures, and in some cases may actually be more pro-cyclical. Ironically, social protection expenditures are not themselves protected.

Assuming that there is an agreement to protect the poor from budget cuts during a crisis, the question becomes: which programmes should be protected? There are no easy answers to this question, and the the information. By the time it is known that actual expenditures have fallen, or that the available credits have not been used, it may be too late. To avoid nonintentional budget cuts due to lags in spending, it is important, after budget allocations have been made, to try to ensure that the budgets are set operationally and maintained at adequate levels, with continuous monitoring of the outlays in order to confirm that the plans are effectively being carried out. answer is bound to be country-specific. Still, one important criterion for the selection of the programmes to protect or expand is their ability to quickly provide income support or its equivalent in kind for the poor. Workfare schemes may help, but policy-makers should be aware that it typically costs more than three dollars to generate one additional dollar in net earnings for the poor through these programmes. Some nutrition and food programmes may also be effective, provided they are well targeted, which is not always the case. Good targeting is one of the key parameters of the costeffectiveness of safety nets. Also, existing social programmes which are not safety nets proper (e.g., job training programmes, social funds, and conditional stipends for school attendance in poor areas) can prove to be valuable delivery mechanisms for emergency assistance when there is limited administrative capacity in the country. Apart from compensating the poor for the likely loss of market-based income which occurs during a crisis, it is also necessary for the government to protect some universal programmes. These would include primary health care and education, as well as health programmes with large externalities. But the most difficult task of all is to identify those programmes that can be reduced, put on hold, or eliminated. Candidates in this respect may include subsidized housing, other subsidies for commodities not consumed mainly by the poor, some social security programmes, and spending on higher education and advanced curative care. While it is often difficult politically to reform these programmes, the need to act during a crisis may facilitate the necessary fundamental changes.

(Original: English) 
APPENDIX

Main risks by age group, and role of social protection in addressing those risks

\begin{tabular}{|c|c|c|c|c|}
\hline Age group & Main risks & Roles of other sectors & $\begin{array}{l}\text { Role of social } \\
\text { protection: insurance }\end{array}$ & $\begin{array}{l}\text { Role of social } \\
\text { protection: assistance }\end{array}$ \\
\hline $0-4$ & - Stunted child development & $\begin{array}{l}\text { - Primary health care services } \\
\text { - Pre-school centres }\end{array}$ & - & - Early child development \\
\hline $5-14$ & $\begin{array}{l}\text { - Low education quality } \\
\text { - Late entry to school } \\
\text { - Late age by grade }\end{array}$ & $\begin{array}{l}\text { - Quality education } \\
\text { - Earlier entry } \\
\text { - Reduced repetition }\end{array}$ & $\begin{array}{l}- \\
-\end{array}$ & $\begin{array}{l}\text { - Scholarships and schooling } \\
\text { incentives }\end{array}$ \\
\hline $15-24$ & $\begin{array}{l}\text { - Low secondary school } \\
\text { completion rates } \\
\text { - Teen pregnancy } \\
\text { - Venereal diseases }\end{array}$ & $\begin{array}{l}\text { - Access to/quality of } \\
\text { secondary education } \\
\text { - Remedial education } \\
\text { - Reproductive health }\end{array}$ & - & $\begin{array}{l}\text { - Scholarships and schooling } \\
\text { incentives }\end{array}$ \\
\hline $25-64$ & $\begin{array}{l}\text { - Low income } \\
\text { (unemployment/ } \\
\text { underemployment) }\end{array}$ & $\begin{array}{l}\text { - Labour-intensive growth } \\
\text { (with emphasis on SMEs) } \\
\text { - Labour market reforms }\end{array}$ & $\begin{array}{l}\text { - Unemployment } \\
\text { insurance }\end{array}$ & $\begin{array}{l}\text { - "Workfare" projects } \\
\text { - Cash transfers } \\
\text { - Job training } \\
\text { - Job search assistance }\end{array}$ \\
\hline $65+$ & $\begin{array}{l}\text { - Low income } \\
\quad \text { (no pension, no assets) }\end{array}$ & & $\begin{array}{l}\text { - Social security } \\
\quad \text { (contributory pensions) }\end{array}$ & $\begin{array}{l}\text { - Income transfer } \\
\quad \text { (non-contributory pensions) }\end{array}$ \\
\hline All groups & $\begin{array}{l}\text { - Low access to and } \\
\text { quality of health care } \\
\text { - Low housing quality } \\
\text { - Low access to basic } \\
\text { infrastructure } \\
\text { - Insecure tenancy } \\
\text { - Risk of flooding }\end{array}$ & $\begin{array}{l}\text { - Better provision of } \\
\text { health services } \\
\text { - Affordable housing } \\
\text { - Investments in basic } \\
\text { infrastructure } \\
\text { - Titling programmes }\end{array}$ & - Health insurance & $\begin{array}{l}\text { - Housing subsidies } \\
\text { - Relocation to safe areas }\end{array}$ \\
\hline
\end{tabular}

Source: Adapted from Arriagada (1999). 


\section{Bibliography}

Arriagada, A.M. (1999): Managing social risk in Argentina, Washington, D.C., World Bank, mimeo.

Basu, K. and P. H. Van (1998): The economics of child labor, The American Economic Review, vol. 88, No. 3, Nashville, Tennessee, American Economic Association.

Besley, T. and R. Kanbur (1988): Food subsidies and poverty alleviation, The Economic Journal, vol. 98, No. 392, Oxford, U.K., Basil Blackwell.

(1993): The principles of targeting, in M. Lipton and J. Van der Gaag (eds.), Including the Poor, Washington, D.C., World Bank.

Castro-Fernández, R. and Q. Wodon (2000): Protecting the unemployed in Chile: From State assistance to individual insurance, Washington, D.C., World Bank, mimeo.

Cornia, G. A. and F. Stewart (1995): Two errors of targeting, in D. Van de Walle and K. Nead (eds.), Public Spending and the Poor: Theory and Evidence, Baltimore, Maryland, Johns Hopkins University Press.

Cunningham, W. (1998): Breadwinner versus care giver: Labor force participation and sectoral choice over the Mexican business cycle, Washington, D.C., World Bank, mimeo.

Dall'Acqua, F. (1991): Economic adjustment and nutrition policies: Evaluation of a school-lunch programme in Brazil, Food and Nutrition Bulletin, vol. 13.

Dar, A. and Z. Tzannatos (1999): Active labor market programs: A review of the evidence from evaluations, Social Protection Discussion Paper No. 9901, Washington, D.C., World Bank.

De Ferranti, D., G. E. Perry, I. S. Gill and L. Serven (2000): Securing our Future in a Global Economy, Washington, D.C., World Bank.

De Janvry, A. and E. Sadoulet (1999): Growth, poverty, and inequality in Latin America: A causal analysis 19701994, Washington, D.C., Inter-American Development Bank (IDB), mimeo.

ESA Consultores (1999): Evaluación ex-post del Fondo Hondureño de Inversión Social, Tegucigalpa.

Ezemenari, K. (1997): The link between public and private interhousehold transfers: Implications for the design of safety net programs in developing countries, American Journal of Agricultural Economics, vol. 79, Ames, Iowa, Latin American and Caribbean Association of Agricultural Economists.

Ezemenari, K. and K. Subbarao (1999): Social Assistance and Poverty-Targeted Programs: A Toolkit for Latin America and the Caribbean, Washington, D.C., World Bank.

Fajnzylber, P. and W. Maloney (1999): Labor demand and trade reform in Latin America, Washington, D.C., World Bank, mimeo.

Ganuza, E., L. Taylor and S. Morley (1998): Política macroeconómica y pobreza en América Latina y el Caribe, Madrid, Ediciones Mundi-Prensa.

Gill, I. (1999): Managing socioeconomic risks in Latin America and the Caribbean, Washington, D.C., World Bank, mimeo.
Glewwe, P. and G. Hall (1998): Are some groups more vulnerable to macroeconomic shocks than others? Hypothesis tests based on panel data from Peru, Journal of Development Economics, vol. 56, No. 1, Amsterdam, The Netherlands, Elsevier Science Publishers, B.V.

Goodman, M., S. Morley, G. Siri and E. Zuckerman (1997): Social Funds in Latin America: Past Performance and Future Role, Washington, D.C., IDB.

Grosh, M. E. (1992): The Jamaican food stamps programme, Food Policy, vol. 17, Stoneham, Massachusetts, Butterworth-Heinemann, Ltd.

(1994): Administering Targeted Social Programs in Latin America: From Platitudes to Practice, Washington, D.C., World Bank.

(1995): Five criteria for choosing among poverty programs, in N. Lustig (ed.), Coping with Austerity: Poverty and Inequality in Latin America, Washington, D.C., The Brookings Institution.

Hicks, N. (1991): Expenditures reductions in developing countries revisited, Journal of International Development, vol. 3, No. 1, West Sussex, U.K., John Wiley \& Sons, Ltd.

Holzmann, R. and S. Jorgensen (1999): Social protection as social risk management: conceptual underpinnings for the social protection sector strategy paper, Social Protection Discussion Paper No. 9904, Washington, D.C., World Bank.

Holzmann, R. and T. Packard (1999): Extending coverage in multi-pillar pension systems: Constraints and hypotheses. Preliminary evidence and future research agenda, Washington, D.C., World Bank, mimeo.

Jacoby, E., S. Cueto and E. Politt (1996): Benefits of a school breakfast programme among Andean children in Huaraz, Peru, Food and Nutrition Bulletin, vol. 17.

Jalan, J. and M. Ravallion (1998): Income gains from workfare and their distribution: Estimates from Argentina's Trabajar program, Washington, D.C., World Bank, mimeo.

Jorgensen, S., M. Grosh and M. Schacter (1992): Bolivia's Answer to Poverty, Economic Crisis and Adjustment: The Emerging Social Fund, Washington, D.C., World Bank.

Karni, E. (1999): Optimal unemployment insurance: A guide to the literature, Social Protection Discussion Paper No. 9906, Washington, D.C., World Bank.

Klugman, J. (1999): Social safety nets and crises, Washington, D.C., World Bank, mimeo.

Levy, S. and E. R. Dávila (1998): Subsidios y política social, Examen, vol. 110.

Lustig, N. (ed.) (1995): Coping with Austerity: Poverty and Inequality in Latin America, Washington, D.C., The Brookings Institution.

(1999): Crisis and the Poor: Socially Responsible Macroeconomics, Presidential address to LACEA 1999, Washington, D.C., The Brookings Institution.

Lustig, N. and O. Arias (forthcoming): Poverty and inequality in Latin America: economic crises and widening returns to skills, Finance and Development, Washington, D.C., International Monetary Fund (IMF). 
Maloney, W (2000): The evaluation of workfare and conditional transfer programs as emergency measures, and a modification to Trabajar, Washington, D.C., World Bank, mimeo.

Nickell, S. (1997): Unemployment and labor market rigidities: Europe versus North America, The Journal of Economic Perspectives, vol. 11, No. 3, Nashville, Tennessee, American Economic Association.

Phillips, M., G. Sáenz, J. Fielder, B. Rogers, P. Tatian, T. Sanghvi and J. Behrman (1995): The Costs and CostEffectiveness of School Feeding and School Bonos Programs in Honduras, Report No. LAC-0657-C-00-0051, Washington, D.C., United States Agency for International Development (USAID).

Pradhan, M., L. Rawlings and G. Ridder (1998): The Bolivian social investment fund: An analysis of baseline data for impact evaluation, The World Bank Economic Review, vol. 12, No. 3, Washington, D.C., World Bank.

Progresa (Education, Health and Nutrition Program) (1999): Más oportunidades para las familias pobres, Mexico City.

Ravallion, M. (1999): Appraising workfare, The World Bank Research Observer, vol. 14, Washington, D.C., World Bank.

(2000): On protecting the poor from fiscal contractions, Washington, D.C., World Bank, mimeo.

Ravallion, M. and Q. Wodon (2000a): Does child labor displace schooling? Evidence on behavioral responses to an enrollment subsidy, The Economic Journal, vol. 110, Oxford, U.K., Basil Blackwell, March.

(2000b): Banking on the poor? Branch placement and nonfarm rural development in Bangladesh, Review of Development Economics, No. 4.

Revenga, A., M. Riboud and H. Tan (1994): The impact of Mexico's retraining program on employment and wages, The World Bank Economic Review, vol. 8, No. 2, Washington, D.C., World Bank.

Rodrik, D. (1999): Why is there so much insecurity in Latin America?, Boston, Harvard University, mimeo, and CEPAL Review, No. 73.

Sahn, D. and H. Alderman (1995): Incentive effects on labor supply of Sri Lanka's rice subsidy, in D. Van de Walle and K. Nead (eds.), Public Spending and the Poor: Theory and Evidence, Baltimore, Maryland, Johns Hopkins University Press.

Skoufias, E., B. Davis and J. Behrman (2000): Evaluación del sistema de selección de familias beneficiarias, in PROGRESA (Programa de Educación, Salud y Alimentación), Progresa, más oportunidades para las familias pobres, Mexico City.
STPS (Secretaría de Trabajo y Previsión Social) (1998): Evaluación del programa de becas de capacitación para desempleados, Mexico City

Subbarao K., A. Bonnerjee, J. Braithwaite, S. Carvalho, K. Ezemenari, C. Graham and A. Thompson (1997): Safety Net Programs and Poverty Reduction: Lessons from Cross-Country Experience, Washington, D.C., World Bank.

Tuck, L. and K. Lindert (1996): From universal food subsidies to a self-targeted program: A case study in Tunisian reform, World Bank discussion paper No. 351, Washington, D.C., World Bank.

University of Chile (1992): Estudio sobre los programas especiales de empleo, Santiago, Chile, Department of Economics.

Wodon, Q. (1997): Targeting the poor using ROC curves, World Development, vol. 25, No. 12, Washington. D.C., The American University.

(2000a): Poverty and policy in Latin America and the Caribbean, World Bank technical paper No. 467, Washington, D.C., World Bank.

(2000b): Public works employment and workfare programs: Optimizing the timing of benefits for poverty reduction, Washington, D.C., World Bank, mimeo.

Wodon, Q., G. González and C. Siaens (2000): Do conditionalities in social programs exclude the poorest? Demand-side schooling interventions in Latin America, Washington, D.C., World Bank, mimeo.

Wodon, Q., N. Hicks, B. Ryan and G. González (1999): Are governments pro-poor? A test based on targeted and social spending during booms and busts, Washington, D.C., World Bank, mimeo.

Wodon, Q. and M. Minowa (1999): Training the urban unemployed: A reevaluation of Mexico's Probecat, Washington, D.C., World Bank, mimeo.

Wodon, Q. and C. Siaens (1999a): Child labor and government programs in Mexico, Washington, D.C., World Bank, mimeo.

(1999b): Food subsidies and consumption inequality in Mexico, Washington, D.C., World Bank, mimeo. (2000): Estimating the cost of child labor, Washington, D.C., World Bank, mimeo.

Wodon, Q. and S. Yitzhaki (2000): Targeted social programs, allocation among beneficiaries, and income inequality, Washington, D.C., World Bank, mimeo.

World Bank (1999): Social protection sector strategy paper, Washington, D.C., mimeo. 